\title{
A Profusion of Chancery Reform
}

James Oldham

Georgetown University Law Center, oldham@law.georgetown.edu

This paper can be downloaded free of charge from:

https://scholarship.law.georgetown.edu/facpub/595

22 Law \& Hist. Rev. 609-614 (2004)

This open-access article is brought to you by the Georgetown Law Library. Posted with permission of the author. Follow this and additional works at: https://scholarship.law.georgetown.edu/facpub

Part of the Legal History Commons 


\section{A Profusion of Chancery Reform}

\section{JAMES OLDHAM}

The refrain that law and equity cannot peaceably cohabit the same court is familiar and persistent. In his 1790 treatise on contracts, Joseph Powell protested that blending law and equity was "subversive of first principles." He claimed, "That a right in itself purely legal cannot be the proper subject of discussion in a jurisdiction purely equitable, and that a right purely equitable, cannot be the proper subject of a purely legal jurisdiction, are axioms that cannot be denied," adding for good measure: "It is a proposition as self-evident as that black is not red, or white black."2 Almost two centuries later, in a provocative 1974 essay called The Death of Contract, Grant Gilmore asserted that the legal doctrine of consideration in contract law and the equitable doctrine of promissory estoppel were like "matter and anti-matter," and "The one thing that is clear is that these two contradictory propositions cannot live comfortably together: in the end one must swallow the other up."3

Gilmore and Powell notwithstanding, law and equity have been able to live together successfully, if occasionally uneasily, for well over a century. In England the crucial procedural event, marking the end of a bumpy journey of at least four decades of fits and starts, was the Judicature Act $1873 .{ }^{4}$ The fact that fusion was finally achieved in $1873^{5}$ is well-known. ${ }^{6}$

1. J. J. Powell, Essay Upon the Law of Contracts and Agreements, 2 vols. (London: For J. Johnson and T. Whieldon, 1790), 1: viii.

2. Ibid., ix.

3. Grant Gilmore, The Death of Contract (Columbus: Ohio State University Press, 1974), 61 .

4. 36 \& 37 Vict., c. 66.

5. Augmented by additional provisions in the Judicature Act 1875 .

6. See generally Patrick Polden, "Mingling the Waters: Personalities, Politics and the Making of the Supreme Court of Judicature," Cambridge Law Journal 61 (2002): 575.

James Oldham is St. Thomas More Professor of Law and Legal History at Georgetown University Law Center <oldham@law.georgetown.edu>. 
Not well-known, however, has been the story of exactly how this happened. Michael Lobban tells that story in meticulous detail with commendable clarity, starting with the early 1800 s and the quarter-century when Chancery was in the hands of John Scott, Lord Chancellor Eldon.

Lobban has clearly spent many long hours thrashing through nineteenth-century parliamentary history and associated pamphlet and popular literature. He has put this hard labor to good use already in earlier work describing the fate of the civil jury in England in the nineteenth and early twentieth centuries. ${ }^{7}$ In "Preparing for Fusion," Lobban gives readers a panoramic view of the dominant personalities in and proposals for Chancery reform in the nineteenth century, as well as of the many obstacles, uncertainties, and vacillations. He states, for example, that when Lord Chancellor Cottenham retired in June 1850, "Once more, the profession was hopelessly divided on how to proceed; and all the old arguments were replayed." 8 Yet enough momentum had by then been produced to keep the process moving forward, and it is interesting to see the reformers seeking out in 1850-51 advice from the great American codifier, David Dudley Field. ${ }^{9}$ By this time, significant reform steps had already been taken. Two new Vice Chancellors had been authorized in 1840; the Six Clerks and the Sworn Clerks had been eliminated in 1842; and much of the piecework fee system for judges and court officers had been converted to annual salaries. ${ }^{10}$ In 1851 a new court of appeal was created; and in 1852, among other measures, the office of master in Chancery was abolished." ${ }^{11}$ This piecemeal process continued, culminating in the Judicature Acts 1873 and 1875.

Yet even with the benefit of the voluminous parliamentary records and secondary sources examined by Lobban, puzzles remain. Was Eldon's famous indecisiveness truly responsible for the picture of Chancery decadence painted by Charles Dickens in Bleak House? Despite contemporary beliefs that this was so, statistical proof was either unavailable, contradictory, or

7. Michael Lobban, "The Strange Life of the English Civil Jury, 1837-1914," in "The Dearest Birth Right of the People of England": The Jury in the History of the Common Law, ed. J. W. Cairns and Grant McLeod (Oxford and Portland, Ore: Hart Publishing, 2002), 173.

8. Michael Lobban, "Preparing for Fusion: Reforming the Nineteenth-Century Court of Chancery, Part I," Law and History Review 22 (2004): 422-23.

9. Ibid., "Part II," n. 94 and 584.

10. Ibid., 568, 570, 573.

11. Ibid., 582-83. In passing, it could be noted that a chronology of enacted reform measures would be extremely helpful to readers. Lobban's narrative moves through a blizzard of proposals, some of which succeeded, but most of which did not, and it is easy to get lost in the many parliamentary meanderings. 
at best, inconclusive. Not until 1840, long after Eldon's departure from office, did anyone actually inspect the Registrars' books to produce reliable data on the number of cases actually heard by the Lord Chancellor. ${ }^{12}$

Each of Lord Eldon's judicial notebooks begins with the following handwritten admonition to himself: "Thou shal't do no unrighteousness in judgment." ${ }^{13}$ Eldon was clearly a conscientious judge who deliberated long, often to excess. A story circulated in the nineteenth century that barrister George Rose was asked one day to substitute for the regular note-taker in Eldon's court, and to give an account of any decision made, and the following lines were Rose's only entries:

Mr. Leach made a speech, Angry, neat, but wrong:

Mr. Hart, on the other part,

Was heavy, dull, and long:

Mr. Parker made the case darker,

Which was dark enough without:

Mr. Cooke cited his book,

And the Chancellor said-“I doubt."14

Despite Eldon's "learned doubtfulness,"15 was he overburdened? His surviving judicial notes supply some useful data. Eldon became Lord Chancellor on April 14, 1801 (though continuing simultaneously as Chief Justice of Common Pleas until May 21); he resigned on February 7, 1806, but resumed office on April 1, 1807, continuing until his resignation on April 30,1827 . Except for a small sprinkling of cases, Eldon's judicial notes cease in early 1814, which coincides with Parliaments's creation of the office of Vice Chancellor in 1813, after which, according to Lobban, "the Lord Chancellor soon ceased to hear original causes."16 For the ten full calendar years from 1801-14 during which Eldon was Lord Chancellor, his judicial notes show the following:

12. Ibid., 569 (describing the documentary research of Edwin Field, which supported the case being made for additional judges).

13. Emphasis added. Eldon's notebooks, manuscripts, and monographs are in the collection of the Georgetown University Law Library.

14. Croake James [J. Paterson], Curiosities of the Law and Lawyers (London: Low, Marston, Searle, and Rivington, 1882), 86-87. Leach, Hart, Parker, and Cooke were leading barristers of the day. Cooke was the author of a well-known treatise on bankruptcy, which is undoubtedly the book he was citing.

15. Lobban, "Part I," 408 (quoting critic John Williams).

16. Ibid., 393. 
Table 1. New and Continued Cases in Chancery Heard by Lord Chancellor Eldon

\begin{tabular}{|c|c|c|c|}
\hline Year & No. of new cases & $\begin{array}{l}\text { No. of cases continued } \\
\text { from earlier year }(s)\end{array}$ & \\
\hline 1802 & 96 & 3 & \\
\hline 1803 & 45 & 9 & \\
\hline 1804 & 61 & 4 & \\
\hline 1805 & 44 & 6 & \\
\hline 1808 & 48 & 0 & \\
\hline 1809 & 28 & 7 & \\
\hline 1810 & 29 & 6 & \\
\hline 1811 & 27 & 3 & \\
\hline 1812 & 38 & 2 & \\
\hline 1813 & 52 & 3 & \\
\hline Total: & 468 & 43 & Grand total: 511 \\
\hline
\end{tabular}

Source: Eldon MSS, Georgetown University Law Library, Washington, D.C.

Apart from the burst of activity in the first year, these figures do indeed reflect a deliberative pace, especially the years showing only seven or eight cases per term, and tend to confirm the critics who pointed to Eldon's "over anxiety to do strict justice."17 The pattern for 1801-13 of about fifty cases per year, however, is substantially higher than the ten cases per year that critic John Williams claimed Eldon heard during the years $1813-21 .^{18}$ Perhaps this was due to the change from hearing original causes to hearing appeals once the Vice Chancellor arrived in 1813. Alternatively, there may discrepancies in sources used to count cases. Many of the cases recorded in Lord Eldon's judicial notes, for example, are unreported.

In 1810, another critic, Michael Taylor, claimed that there were 140 Chancery causes pending, which would take eight years to resolve. Taylor and other Whig activists, according to Lobban, sought to have a committee formed to get to the bottom of the delays, but the Tory resistance of Lord Redesdale ${ }^{19}$ and others forestalled this effort and persuaded the reformers of the moment that what was needed was another judge, eventually resulting in the creation in 1813 of the office of Vice Chancellor. Redesdale, the former John Mitford, is described by Lobban merely as the former Lord Chancellor of Ireland, but it is worth noting that Redesdale (Mitford) had a large investment in Chancery procedures as they stood. Redesdale (Mitford) was called to the bar in 1777, and three years later, he published A Treatise on Pleadings in Suits in the Court of Chancery by

17. Ibid., 404, quoting The Times, 8 March 1811.

18. Ibid., 408.

19. Ibid., 409. 
English Bill, ${ }^{20}$ which quickly became accepted as authoritative ${ }^{21}$ and helped Mitford acquire a large Chancery practice. ${ }^{22}$

Reformer Taylor and those who agreed with him, on the other hand, claimed that the predicable result of creating a Vice Chancellor would be that every case would be appealed from the Vice Chancellor to the Chancellor, accomplishing nothing but the insertion of another layer of adjudication and more delay. Interestingly, Eldon in his retirement (1730) agreed, writing in a letter to Lyndhurst that the office of Vice Chancellor "retarded my progress at an enormous Expense to my Suitors"- "hardly anything passed for some Time, in the Vice Chancellor's Court, and under different Vice Chancellors, which was not made, almost instantaneously, the Subject of Appeal."'23

The Vice Chancellor, in fact, is something of a phantom in Lobban's narrative. If the office was almost wholly counterproductive, as suggested, how did Parliament come to be persuaded by 1840 that two new Vice Chancellors were needed, after which, according to Lobban, "the problem of arrears ... fell into abeyance once more"? ${ }^{24}$ And exactly what did happen in the 1810s after the office of Vice Chancellor was created? Lobban's Figure 3 shows the causes ready for hearing at the end of Michaelmas, and after oscillations from about ten to 150 cases from 1760-1800, there is a slow rise to over 300 in 1813 and then a spike to above 800 for 1816-17, followed by a plummet to 200 . What might account for these dramatic variations? There seems here to be a story untold.

Inevitably, research such as that in Michael Lobban's illuminating study, "Preparing for Fusion," answers many questions but raises many new ones. Those who in the future reconsider the variegated elements of Chancery reform will have the great advantage of the story that Lobban has so laboriously and carefully told. Lobban escorts the reader through a near-impen-

20. John Mitford, A Treatise on Pleadings in Suits in the Court of Chancery by English Bill (London: W. Owen, 1780).

21. See William Holdsworth, History of English Law, 17 vols. (London: Methuen 1903 72; reprint 16 vols., London: Methuen, Sweet and Maxwell, 1966), 12:185; Dictionary of National Biography, compact ed., 2 vols. (Oxford: Oxford University Press, 1975), s.v. John Mitford (quoting the appraisal of Sir Thomas Plumer [Jacob \& Walker Reports, ii 151-52] that Mitford's treatise reduced "the whole subject to a system with such universally acknowledged learning, accuracy, and discrimination, as to have been ever since received by the whole profession as an authoritative standard and guide"). Lord Eldon himself reportedly described Mitford's book as "a wonderful effort to collect what is to be deduced from authorities speaking so little what is clear." Dictionary of National Biography, s.v. Mitford.

22. Mitford also served as Solicitor General of England, 1793-99, and as Attorney General, 1799-1802, before his appointment as Lord Chancellor of Ireland.

23. Lobban, "Part I," 417.

24. Ibid., 422. 
etrable nineteenth-century parliamentary forest, emerging on the threshold of the 1873 Judicature Act. Piecemeal legislation along the way eliminated some of the obvious drags on Chancery case-handling, ${ }^{25}$ and a brightened Chancery future seemed to lie ahead. As was said by a contributor to the Edinburgh Review in 1875: "The Judicature Act crowns the edifice of legal improvement, which has been slowly built up since the beginning of the present century." 26 Hopes for a more efficient court were, however, soon dashed. Instead of a bright new day, increased costs, confused rules of pleading, and an increased level of appeals darkened the dispensation of justice by what was now called the High Court of Justice.$^{27}$ Fusion of law and equity had been accomplished, although perhaps it did "no more than fuse the administration of law and equity." 28 Along the way, however, it had been discovered that law and equity were not "matter and anti-matter""for many years before the Judicature Acts, law and equity had complemented each other harmoniously."29

25. Apart from those that have been mentioned was the crushingly inefficient requirement that all parties with any interest whatever in a case attend the court for any hearing of any aspect of the case.

26. Edinburgh Review 14 (1875): 179, 180, as quoted in A. S. Manchester, A Modern Legal History of England and Wales, 1750-1950 (London: Butterworths, 1980), 149.

27. Ibid., 148-49.

28. Ibid., 149.

29. Ibid. 